\title{
PENGARUH MARKETING ENDORSER DAN KREATIVITAS DALAM IKLAN SEPEDA MOTOR HONDA TERHADAP PERSEPSI KONSUMEN (Studi pada Masyarakat Lingkungan VI Helvetia Tengah Medan)
}

\author{
Hesti Sabrina \\ Dosen Fakultas Ekonomi dan Bisnis Universitas Medan Area
}

\begin{abstract}
Abstrak
Penelitian ini bertujuan untuk mengetahui apakah terdapat pengaruh yang positif antara marketing endorser dan kreativitas dalam iklan sepeda motor Honda terhadap persepsi konsumen. Penelitian ini dilakukan pada masyarakat Lingkungan VI Kelurahan Helvetia Tengah Medan dengan sampel sebanyak 81 responden yang diambil secara purposive sampling. Teknik analisis data yang digunakan adalah regresi linear berganda dengan rumus $Y=a+b 1 X 1+b 2 X 2$ dan untuk mengetahui besarnya pengaruh marketing endorser dan kreativitas terhadap persepsi konsumen digunakan rumus determinasi $\left(R^{2}\right)$. Setelah dilakukan pengolahan data dengan bantuan SPSS for Windows 22.0 maka diperoleh persamaan regresi $Y=23.289+0.283 X 1+0.255 X 2$. Selanjutnya diperoleh koefisien determinasi $\left(R^{2}\right)$ sebesar 0.210 atau $21 \%$ yang berarti variabel marketing endorser dan kreativitas mempengaruhi variabel persepsi konsumen pada masyarakat Lingkungan VI Kelurahan Helvetia Tengah Medan sebesar 21\% dan selebihnya dipengaruhi faktor-faktor lain. Untuk menguji hipotesis dalam penelitian ini digunakan uji t, kemudian diperoleh $t_{\text {hitung }}$ masing-masing variabel yaitu 2.598 (marketing endorser), 2.322 (kreativitas) sedangkan $t_{\text {tabel }}$ sebesar 1.667 ( $\left.t_{\text {hitung }}>t_{\text {tabel }}\right)$ yang berarti hipotesis diterima, yaitu ada pengaruh yang positif antara marketing endorser dan kreativitas dalam iklan sepeda motor Honda terhadap persepsi konsumen pada masyarakar Lingkungan VI Kelurahan Helvetia Tengah Medan. Selain itu juga dilakukan uji $F\left(\right.$ ANOVA) menghasilkan $F_{\text {hitung }}>F_{\text {tabel }}=10.379>3.44$. Dengan demikian variabel marketing endorser dan kreativitas dalam iklan produk sepeda motor Honda secara bersama-sama berpengaruh terhadap persepsi konsumen pada masyarakat Lingkungan VI Kelurahan Helvetia Tengah Medan.
\end{abstract}

Kata kunci: Marketing Endorser, Kreativitas, Persepsi Konsumen

\section{PENDAHULUAN}

Perusahaan akan selalu mengembangkan dan mencari ide-ide kreatif untuk dapat meningkatkan penjualannya dan tentu saja memuaskan kebutuhan pelanggannya. Iklan adalah salah satu pilihan yang ditempuh oleh perusahaan untuk berkomunikasi dengan publiknya. Melalui iklan, perusahaan/pemasar berusaha mempengaruhi perasaan, pengetahuan, kepercayaan, sikap dan citra konsumen terhadap produk atau merek. Namun, tidak banyak orang yang bersedia untuk memperhatikan iklan, sebab dianggap menggangu karena muncul pada saat sedang asyik menikmati siaran televisi.

Bagi stasiun televisi dan para produsen, iklan merupakan hal yang sangat penting. Bagi stasiun televisi, iklan merupakan sumber penghasilan yang cukup besar. Jadi tidaklah heran jika banyak program televisi yang disesaki oleh iklan. Terutama pada acara-acara yang banyak diminati oleh pemirsa. Sedangkan bagi para produsen barang maupun jasa, iklan merupakan sarana yang efektif untuk 
menyampaikan pesan/ informasi mengenai produk yang dihasilkannya.

Penggunaan selebriti yang telah dikenal oleh masyarakat sebagai endorser merupakan suatu strategi dalam periklanan yang dimaksudkan untuk membuat sebuah iklan menjadi lebih menarik dan membentuk persepsi konsumen mengenai produk ataupun merek. Sikap positif terhadap artis akan membentuk sikap yang positif juga terhadap produk/merek.

$$
\text { Cara lain yang dapat }
$$

dilakukan untuk membuat iklan menjadi lebih menarik adalah dengan menambahkan kreativitas pada iklan. Para pengiklan menggunakan kreativitas dengan harapan akan bisa mencapai tujuan komunikasi, yaitu memperoleh perhatian, bimbingan pemahaman konsumen tentang pernyataan-pernyataan yang diiklankan.dan akhirnya akan menciptakan tindakan pembelian oleh pelanggan.

Persepsi menjadi sangat penting untuk diteliti karena memiliki kaitan yang cukup erat dengan iklan dan tindakan pembelian konsumen pada akhirnya. Persepsi yang baik pada iklan akan membentuk tanggapan yang baik pula terhadap produk dan pada akhirnya akan mempengaruhi minat beli dari konsumen itu sendiri.

Honda adalah salah satu produsen sepeda motor yang cukup terkemuka di Indonesia dan masuk kedalam kategori iklan paling menarik dan kreatif versi Survey One (dalam majalah Marketing,2015).

Daya tarik iklan Honda ini dapat dilihat dari pemilihan selebritiselebriti yang cukup terkenal dan menarik serta ceritanya yang lucu dan sederhana tetapi mudah dimengerti.
Keberhasilan iklan Honda menancap dibenak konsumen karena konsisten dalam penyampaian pesan yang sama dalam setiap iklannya. Hasilnya iklan Honda tidak saja dianggap menarik karena endorsernya tetapi juga paling kreatif.

Masyarakat lingkungan VI Helvetia Tengah Medan terletak di Kecamatan Medan Helvetia dengan jumlah penduduk sebesar 1614 jiwa atau $423 \mathrm{KK}$. Masyarakat lingkungan VI Helvetia Tengah Medan merupakan masyarakat yang sangat pluralis karena terdiri dari berbagai macam suku, agama, budaya, tingkat ekonomi yang berbeda-beda. Masyarakat lingkungan VI Helvetia Tengah Medan sangat potensial untuk menjadi objek dalam riset pemasaran, karena kebanyakan masyarakat menggunakan sepeda motor sebagai alat transportasi seharihari. Dan sebagaimana masyarakat lainnya juga sering melihat tayangan iklan baik melalui media cetak maupun media elektronik.

\section{METODE PENELITIAN \\ Lokasi Penelitian}

Penelitian ini dilakukan terhadap masyarakat yang berlokasi pada Lingkungan VI Kelurahan Helvetia Tengah Kecamatan Medan Helvetia Medan.

\section{Populasi dan Sampel}

Adapun yang menjadi populasi dalam penelitian ini adalah masyarakat yang bertempat tinggal di Lingkungan VI Helvetia Tengah Medan, yang berjumlah 423 kepala keluarga. Penentuan sampel dalam penelitian ini menggunakan rumus Slovin (dalam Umar,2002: 141) 


$$
n=\frac{N}{1+N e^{2}}
$$

Keterangan :

$\mathrm{n}=$ ukuran sampel

$\mathrm{N}=$ ukuran populasi

e = persen kelonggaran/

ketidaktelitian karena

kesalahan pengambilan

sampel yang masih dapat

ditolerir.

Dari data populasi diatas dan dengan persentase kelonggaran $10 \%$, maka sampel dalam penelitian ini adalah :

$$
\begin{gathered}
n=\frac{N}{1+N e^{2}}= \\
\frac{423}{1+423\left(0.1^{2}\right)}=\frac{423}{1+4.23}=80.879=
\end{gathered}
$$

81 responden

Penelitian dilakukan terhadap 81 responden selama lebih kurang 1 minggu. Penelitian ini dilakukan dengan cara purposive sampling yaitu teknik pengambilan sampel dengan tujuan tertentu, dengan kriteria sampel adalah orang yang pernah melihat/menonton iklan sepeda motor Honda.

\section{Variabel Penelitian dan Defenisi Operasional \\ Variabel Penelitian}

Adapun yang menjadi variebel dalam penelitian penelitian ini adalah

1. Variabel bebas pertama (X1) : Marketing endorser

2. Variabel bebas kedua (X2) : Kreativitas

3. Variabel terikat (Y) : Persepsi Konsumen

\section{Defenisi Operasional}

1. Marketing endorser adalah. merupakan kegiatan pemasaran yang berhubungan erat dengan para bintang atau artis yang menjadi pendorong sebuah produk.

2. Kreativitas yang dimaksud disini adalah pemakaian kreativitas dalam iklan yang dilakukan dengan menambahkan unsur-unsur baru dan hal yang berbeda sehingga membuat orang mudah mengingat pesan dan mempengaruhi pandangan mereka terhadap produk yang diiklankan.

3. Persepsi konsumen adalah suatu proses dimana individu diekspos untuk menerima informasi, memperhatikan informasi tersebut, dan memahaminya.

\section{Teknik Analisa Data}

Adapun teknik analisa data yang digunakan dalam penelitian ini adalah :

Untuk mengetahui pengaruh variabel bebas terhadap variabel terikat digunakan teknik data dengan menggunakan analisis statistik regresi ganda sebagai berikut :

$$
\begin{aligned}
& \mathbf{Y = a}+\mathbf{b}_{\mathbf{1}} \mathbf{X}_{\mathbf{1}}+\mathbf{b}_{\mathbf{2}} \mathbf{X}_{\mathbf{2}} \\
& \text { Dimana : } \\
& \mathrm{Y}=\text { Persepsi Konsumen } \\
& \mathrm{X}_{1} \quad=\text { Marketing Endorser } \\
& \mathrm{X}_{2}=\text { Kreativitas } \\
& \mathrm{a} \quad=\text { Bilangan Konstanta } \\
& \mathrm{b}_{1}=\text { Koefisien Regresi } \\
& \text { Marketing endorser } \\
& \mathrm{b}_{2}=\text { Koefisien Regresi } \\
& \text { Kreativitas }
\end{aligned}
$$

\section{Pengujian Hipotesis}

Uji t (Parsial)

Sebelum melihat hasil pengujian terhadap hipotesis, perlu diketahui bahwa yang menjadi hipotesis statistik dalam penelitian ini adalah: 
Ha : Ada pengaruh antara marketing endorser dan kreativitas dalam iklan sepeda motor Honda terhadap persepsi konsumen

Ho : Tidak ada pengaruh antara marketing endorser dan kreativitas dalam iklan sepeda motor Honda terhadap persepsi konsumen

Dengan membandingkan antara $t$ hitung dengan $\mathrm{t}$ tabel akan disimpulkan bahwa :

- Jika t hitung $>\mathrm{t}$ tabel, maka Ha diterima

- Jika t hitung < t tabel, maka Ha ditolak

\section{Uji F (Simultan)}

Uji $\mathrm{F}$ ini berdistribusi $\mathrm{F}$ dengan $\mathrm{dk}$ pembilang $=\mathrm{k}$ dan $\mathrm{dk}$ penyebut $=(\mathrm{n}-$ $\mathrm{k}-1)$.

Bila F hitung $\geq \mathrm{F}$ tabel, pada taraf signifikansi 95\% maka hipotesis yang diajukan diterima.

- $\quad$ Bila F hitung $\leq$ F tabel, pada taraf maka hipotesis yang diajukan ditolak.

Dan untuk mempermudah pengolahan data diatas peneliti menggunakan bantuan SPSS (Statistical package for the Social Science).

\section{HASIL PENELITIAN DAN \\ PEMABAHASAN \\ Hasil Penelitian \\ Analisis Regresi Berganda}

Analisis regresi berganda digunakan untuk mengetahui pengaruh marketing endorser dan kreativitas terhadap persepsi konsumen atas iklan sepeda motor Honda.

Model regresi berganda dengan satu variabel dependen (Y) yakni persepsi konsumen dan 2 variabel independen (X) yakni Marketing Endorser (X1) dan Kreativitas (X2) adalah sebagai berikut:

$$
\mathbf{Y}=\mathbf{a}+\mathbf{b} \mathbf{X} \mathbf{1}+\mathbf{b} \mathbf{X} \mathbf{2}
$$

Berdasarkan hasil analisis regresi berganda yang dilakukan, diperoleh persyaratan regresi sebagai berikut:

$\mathrm{Y}=\mathbf{2 3 . 2 8 9}+\mathbf{0 . 2 8 3} \mathrm{X} 1+\mathbf{0 . 2 5 5} \mathrm{X2}$

Persamaan diatas dapat dijelaskan sebagai berikut:

- Konstanta sebesar 23.289 menyatakan bahwa jika tidak menggunakan marketing endorser dan kreativitas dalam iklan, maka persepsi konsumen adalah sebesar 23.289 (asumsi faktor lain kostan)

- Konstanta X1 sebesar 0, 283 menyatakan bahwa setiap melakukan kebijakan marketing endorser sebesar satu akan mempengaruhi persepsi konsumen sebesar 0 , 283 (asumsi faktor lain kostan)

- Koefisien X2 sebesar 0, 255 menyatakan bahwa setiap melakukan kebijakan kreativitas sebesar satu akan mempengaruhi persepsi konsumen sebesar $0, \quad 255$ (asumsi faktor lain kostan)

\section{Uji t (Parsial)}

Hasil uji t yang diperoleh dari tabel out put SPSS 23.0 windows adalah (3.897), (2.598), (2.322). Sedangkan $t$ tabel pada taraf signifikansi 95\% dengan alpha 5\% dan derajat kebebasan $(\mathrm{df})=81-3=$ 78 adalah 1, 667. Berdasarkan hal tersebut dapat dilihat bahwa hasil uji $\mathrm{t}$ hitung intercept (3.897) $>\mathrm{t}$ tabel $(1,667)$, untuk koefisien variabel marketing endorser (X1) diperoleh t 
hitung $(2.598)>\mathrm{t}$ tabel $(1,667)$, dan untuk koefisien variabel kreativitas (X2) diperoleh $\mathrm{t}$ hitung $(2.322)>\mathrm{t}$ tabel $(1,667)$.

Berdasarkan uraian tersebut diatas dapat dilihat $\mathrm{t}$ hitung $>\mathrm{t}$ tabel sehingga dapat disimpulkan bahwa hipotesis Ha diterima. Dengan kata lain marketing endorser dan kreativitas dalam iklan berpengaruh secara positif terhadap persepsi konsumen.

\section{Uji F (Simultan)}

Berdasarkan hasil pengujian statistik (uji F/ ANOVA) pada hasil output pada tabel ANOVA sebagai berikut: Berdasarkan hasil pengolahan SPSS 23,0 windows nilai $F_{\text {hitung }}=$ 10.379. Setalah mengetahui besarnya $F_{\text {hitung maka akan dibandingkan }}$ dengan $F_{\text {tabel }}$ yang diperoleh, dengan perhitungan sebagai berikut $\mathrm{F}_{\text {tabel }}$ diperoleh dengan $\mathrm{k}=2$, derajat kebebasan $=81-2-1=78$ dan taraf kesalahan 5\% adalah 3.44.

Kriteria uji hipotesis dalam penelitian ini adalah sebagai berikut:

- Bila $F_{\text {hitung }} \geq F_{\text {tabel, }}$ maka Ha diterima dan Ho ditolak.

- Bila $F_{\text {hitung }} \leq \mathrm{F}_{\text {tabel, }}$ maka Ha ditolak dan Ho diterima.

Dengan demikian $\mathrm{F}_{\text {hitung }}>$ $\mathrm{F}_{\text {tabel }}=10.379>3.44$, maka $\mathrm{Ha}$ diterima dan Ho ditolak. Dengan kata lain, marketing endorser dan kreativitas secara bersama-sama mempunyai pengaruh yang positif terhadap persepsi konsumen.

\section{$\mathbf{U j i}^{\mathbf{2}}$ (R square)}

Uji $R^{2}$ ( $R$ square) dilakukan untuk mengetahui sumbangan atau kontribusi antar variabel-variabel independen (X1) secara bersamasama terhadap variabel dependen (Y). Pada hasil diatas dapat kita lihat koefisien korelasi $\left(\mathrm{R}^{2}\right)$ yang diperoleh adalah 0,210 artinya variabel marketing endorser dan kreativitas dalam iklan secara bersama-sama menjelaskan variabel persepsi konsumen sebesar $21 \%$ dan sisanya $79 \%$ dijelaskan oleh variabel lain yang tidak dimasukkan dalam estimasi model.

\section{Pembahasan Penelitian}

Pengaruh Marketing Endorser (X1) Terhadap Persepsi Konsumen (Y)

Temuan penelitian ini menunjukkan bahwa variabel Marketing Endorser dalam iklan sepeda motor Honda mempunyai pengaruh yang signifikan terhadap persepsi konsumen. Hal ini sesuai dengan pendapat Rossiter dan Percy (dalam Wahyuni : 2007) yang mengatakan bahwa " presenter iklan mempunyai pengaruh yang berarti terhadap sikap khalayak pada merek yang diiklankan.

Menurut Kotler (dalam Royan, 2004: 8) “ seorang selebriti yang sangat berpengaruh disebabkan karena memiliki kredibilitas yang didukung oleh keahlian, sikap dapat dipercaya, dan adanya kesukaan". Penulis setuju dengan pendapat ini karena dari penelitian ditemukan bahwa sebanyak $37 \%$ responden menjawab sangat setuju dan $63 \%$ setuju bahwa selebriti yang digunakan sebagai endorser Honda adalah selebriti-selebriti yang sudah cukup familiar dan disukai dimata masyarakat.

Oleh karena endorser yang digunakan dalam iklan tersebut adalah selebriti yang cukup familiar dan mempunyai citra positif dimata masyarakat, membuat persepsi yang positif pula terhadap produk yang 
diiklankan. Hal ini dilihat dari pendapat responden atas ketertarikan untuk membeli produk yang diiklankan sebanyak $23.5 \%$ yang menjawab sangat setuju dan $66.7 \%$ dengan jawaban setuju.

Dari pembahasan ini penulis menyimpulkan bahwa marketing endorser dalam iklan Honda berpengaruh positif terhadap persepsi konsumen pada masyarakat Lingk. VI Helvetia Tengah Medan.

Pengaruh Kreativitas (X2) Terhadap Persepsi Konsumen (Y) Temuan penelitian ini menunjukkan bahwa variabel kreativitas dalam iklan sepeda motor Honda mempunyai pengaruh yang signifikan terhadap persepsi konsumen. Iklan sepeda motor Honda adalah iklan yang disukai oleh sebagian besar responden karena kreativitas yang terkandung di dalamnya. 59\% responden menjawab sangat setuju bahwa iklan tersebut adalah iklan yang disukai sedangkan sisanya menjawab setuju dengan presentase $40.7 \%$. Melihat hal ini penulis setuju terhadap pendapat $\mathrm{AC}$ Nielson (dalam Wahyuni : 2007) yang menyatakan bahwa

iklan kreativitas meraih peluang paling tinggi $(43 \%)$ menyebabkan iklan tersebut disukai pemirsa". Adanya kreativitas dalam iklan akan menarik banyak pemirsa.

Dari jawaban yang diberikan responden diketahui setelah melihat iklan tersebut mereka memiliki persepsi yang baik terhadap produk yang diiklankan. Hal ini ditunjukkan dengan ketertarikan untuk membeli produk dengan presentase jawaban

persepsi yang positif pula terhadap produk yang diiklankan, sehingga sangat setuju $37 \%$ dan presentase jawaban setuju $55.6 \%$.

Hal tersebut diatas sejalan dengan pendapat Shimp (2003: 471) yang menyatakan bahwa "kreativitas digunakan dalam iklan dengan maksud untuk memperoleh perhatian, bimbingan pemahaman konsumen tentang pernyataan-pernyataan produk, mempengaruhi sikap dan mempengaruhi reliabilitas dari pernyataan-pernyataan yang diiklankan dan pada akhirnya akan menciptakan tindakan pembelian oleh pelanggan". Dari pembahasan ini penulis menyimpulkan bahwa kreativitas dalam iklan Honda berpengaruh positif terhadap persepsi konsumen pada masyarakat Lingk. VI Helvetia Tengah Medan.

Pengaruh Marketing Endorser (X1) Dan Kreativitas (X2) Terhadap Persepsi Konsumen (Y)

Dari penelitian dapat dilihat bahwa marketing endorser dan kreativitas memiliki pengaruh terhadap persepsi konsumen sebesar $21 \%$ dan sisanya dipengaruhi oleh faktor-faktor lain.

Iklan berusaha merebut perhatian pemirsa dengan menghadirkan selebriti sebagai endorser dan kreativitas dalam iklan. Persepsi yang baik atas selebriti yang mengiklankan suatu produk akan menimbulkan persepsi yang baik pula pada produk yang diklankannya. Begitu juga halnya dengan kreativitas dalam iklan. Sebahagian besar khalayak lebih tertarik dan lebih memperhatikan iklan dengan unsur kreativitas didalamnya. Persepsi yang positif terhadap iklan dengan kreativitas akan menyebabkan 
iklan maupun produk yang diiklankan akan dengan mudah menancap dibenak mereka.

Persepsi yang baik atas iklan dan produk yang diiklankan pada akhirnya akan menciptakan tindakan pembelian atas produk yang diiklankan. Sebab endorser dan kreativitas dalam iklan tersebut menyebabkan iklan tersebut mudah diingat selanjutnya ketika khalayak membutuhkan produk tersebut, mak merek produk sudah berada dalam ingatan mereka dan akan dikeluarkan dalam bentuk aktivitas nyata yaitu tindakan pembelian. Hal ini dapat dibuktikan dari wawancara penulis denagn responden bahwa 81 orang responden 32 orang responden menggunakan produk Honda, 11 orang tidak memiliki sepeda motor dan 38. Dari pembahasan ini penulis menyimpulkan bahwa marketing endorser dan kreativitas dalam iklan Honda berpengaruh positif terhadap persepsi konsumen pada masyarakat Lingk. VI Helvetia Tengah Medan.

\section{PENUTUP}

1. Marketing endorser dalam iklan Honda berpengaruh positif terhadap persepsi konsumen pada masyarakat Lingk. VI Helvetia Tengah Medan.

2. Kreativitas dalam iklan Honda berpengaruh positif terhadap persepsi konsumen pada masyarakat Lingk. VI Helvetia Tengah Medan.

3. Marketing endorser dan kreativitas dalam iklan Honda berpengaruh positif terhadap persepsi konsumen pada masyarakat Lingk. VI Helvetia Tengah Medan.

\section{DAFTAR PUSTAKA}

Assauri, Sofjan. 1999. Manajemen Pemasaran. Jakarta : PT. Raja Grafindo Persada

Boyd, dkk. 2000. Manajemen Pemasaran. Jakarta: Erlangga

Kotler, Philip. 2002. Manajemen Pemasaran. Edisi Millenium. Jakarta : Salemba Empat

Susanto AB. 2000. Manajemen Pemasaran diIndonesia. Jakarta: Salemba Empat

Lamb, Hair, McDaniel. 2001. Pemasaran. Buku 2. Jakarta : Salemba Empat

Minor, M. Mowen, John. 2002. Perilaku Konsumen. Jilid 1. Jakarta :Salemba Empat

Royan, Frans. 2004. Marketing Selebrities. Jakarta : Gramedia

Santoso, Singgih, 2001, Mengolah Data Statistik Secara Profesional, PT. Alex Media Komputindo, Jakarta.

Sekaran, Uma, 2006, Metode Penelitian untuk Bisnis, Edisi Keempat, Penerjemah: Kwan Men Yon, Salemba Empat, Jakarta.

Shimp, Terrence. A, 2003, Periklanan Promosi . Jilid Satu, Jakarta, Erlangga.

Sugiyono. 2005. Metodologi Penelitian Bisnis. Bandung : CV. ALFABETA

Tjiptono, Fandy. 1997. Strategi Pemasaran. Yogyakarta : Andi

Umar, Husein. 1999. Metode Penelitian Untuk Skripsi dan Tesis Bisnis. Jakarta : PT. Raja Grafindo Persada 